УДК $1.167 / 168+001.89$

DOI https://doi.org/10.32837/apfs.v0i32.1019

Л. В. Герасименко

ORCID ID: https://orcid.org/0000-0003-3725-8681 доктор педагогічних наук, доцент, професор кафедри психологї̈, педагогіки та філософї Кременчуиького національного університету імені Михайла Остроградського

Г.О. Лебединська

ORCID ID: https://orcid.org/0000-0001-9320-6240 кандидат політичних наук,

доцент кафедри психологї, педагогіки та філософії

Кременчущького національного університету ілені Михайла Остроградського

\title{
ПРОБЛЕМА НАСЛІДКІВ МАСОВІЗАЦІї НАУКОВОЇ ДІЯЛЬНОСТІ
}

Постановка проблеми. Масове суспільство і масова культура багато в чому визначають особливості нашого часу і впливають на різні сфери життєдіяльності, демонструючи значне збільшення кількості носіїв її ціннісних орієнтацій. Масовізація - процес та результат формування масового суспільства з характерним йому духовним виміром - масовою культурою. Філософи вже декілька десятиліть обговорюють проблеми масового суспільства, яке характеризується стандартизованими процесами виробництва й споживання, конформізмом та пануванням стереотипів. Процеси масовізації впливають на всі сфери соціокультурного життя сучасної цивілізації, зокрема і ті, які традиційно вважалися і вважаються елітарними, творчими, вільними від масових тенденцій та станів. Однією з них є сфера науки, буття якої (як складника суспільства) містить «відбиток культури» [6, с. 277], а також схильність до комплексної масовізації. Наука є інтелектуальною квінтесенцією сучасної культури, невід'ємною частиною та продовженням її духовного, ментального та аксіологічного простору.

Перебуваючи в контексті сучасних соціальних і культурних процесів, наука не може не зазнавати певних змін. Осмислення їх є актуальним не лише 3 точки зору необхідності більш точного і глибокого розуміння специфіки сучасної науки в культурі, а й із позиції турботи про майбутне людства, в якому досягнення науки відіграють одну з провідних ролей. Масовізація наукового знання, з одного боку, привела до значного зростання його обсягу в культурі, з іншого - сприяла збільшенню ролі прикладного знання, його ціннісного домінування над фундаментальним знанням.

Мета статті - з'ясувати наслідки масовізації науки як соціального інституту та галузі знання.

Виклад основного матеріалу. Проблемі масової культури та масового суспільства присвячено значну кількість досліджень, у яких окреслюється різне ставлення до цих феноменів. Так, Т. Адорно, Н. Бердяєв, Р. Лебон, Р. Маркузе, Р. Міллс,
3. Московичі, Ф. Ніцше, Х. Ортегі-і-Гассет, М. Хоркхаймер, З. Фрейд, У. Еко, К. Ясперс та ін. у своїх дослідженнях висловлюють негативне ставлення до масової культури. Із середини $\mathrm{XX}$ століття серед філософів поширюється тенденція до легітимізації масової культури, в якій бачився новий етап розвитку цивілізації (Д. Белл, Е. Тоффлер, А. Турен, Е. Шилз, ж. Деррида, М. Фуко та ін.). Проте цілісно проблема масовізації науки наразі є нерозробленою і тільки потрапляє в коло уваги дослідників.

Розвиток науки у XX столітті був стрімким i суперечливим, характеризувався низкою парадигмальних криз і світоглядних революцій. На цій хвилі, а також під впливом тенденцій масового суспільства, аксіологічні імпульси якого неминуче проникали в науку, наукове життя і діяльність поступово втрачали історично властивий їм відтінок елітарності, винятковості, стаючи все більш масовими, відкритими, загальнодоступними. "Наприкінці XIX - на початку XX століття відбувається якісна зміна в розвитку науки, яка починає усвідомлюватися як продуктивна сила суспільства, що значно впливала на майже всі сторони його життя. Формується так звана «велика наука», яка характеризується збільшенням фінансових витрат на науку, кількості науковців, частки прикладних досліджень, необхідністю управління, планування, організації та прогнозування розвитку» [3, с. 68].

У цьому контексті справедливо і коректно звучать слова Х. Ортегі-і-Гассета: «У результаті «людина науки» виявляється прототипом масової людини. I не епізодично, не в силу якоїсь суто особистої неповноцінності, а тому, що сама наука - джерело цивілізації - закономірно перетворює його на масову людину» [8, с. 103].

Навіть за останні роки наука зазнала серйозних трансформацій у процесі свого перетворення на велику індустрію. Сьогодні сфера науки займає набагато більше місця, складніше і більшою мірою інтегрована в інші суспільні сектори, ніж це було в 
1990-ті роки. Нині вона перетворилася на глобальну індустрію, в якій 7-9 млн дослідників щорічно публікують 2,5 млн статей (і це лише ті, які містяться в провідних базах даних). Кількість статей у галузі природничих та технічних наук за останні 25 років у світі зросла більше ніж на $350 \%$ [11].

Швидкі інституційні трансформації, що радикально змінюються, призводять до деформації традиційної системи цінностей. Так, польський соціолог Я. Гочковський [8] усвідомлює проблему численних відхилень працівників науки від норм наукового етосу. Однією з основних причин цього він уважає значне зростання кількості вчених («велика наука»). Термін «велика наука», що ввійшов у світовий побут, учені характеризують як нову велику сферу наукової та науково-технічної діяльності, теоретичних, прикладних досліджень і розробок. Масовий характер набуває залучення вчених у виробничі лабораторії та конструкторські відділи підприємств та фірм, де вони вирішують конкретні завдання, які диктують потреби часу. Як наслідок, наука, всебічно відповідаючи потребам суспільного розвитку, стала масовим заняттям, у контрольованих і координованих інституційних масштабах якого вчений закономірно перетворювався на пересічного найманого працівника, що пропонує свою працю і професійні здібності на зростальному і конкурентному ринку інтелекту. Головним негативним наслідком комерціалізації науки стає зниження рівня світоглядної та соціальної відповідальності їі представників, які в гонитві за економічним прибутком не бачать (чи воліють не бачити) можливих негативних наслідків своєї діяльності. 3 приходом «масової людини» в науку дотримання етосу науки неминуче розмиватиметься. У цих умовах справжнім носієм етосу науки (який стоїть на варті збереження ідентичності науки загалом) може бути лише деяка меншість «справжніх" учених-дослідників, яка твердо дотримується суворих норм науки.

Масовізація науки також є потужним джерелом іiї всебічної формалізації - зведення активності дослідника до механізованого набору суто умовних методів, прийомів та операцій, що зовні маскують її під професійну наукову роботу. У межах процесу формалізації, що набирає обертів, усе більша кількість учених (носіїв ціннісних установок масової культури, що воліє споживати, а не творити) починають створювати лише видимість власної кропіткої наукової праці, насправді займаючись реферуванням чужих текстів, нерідко вдаючись при цьому до компіляції, плагіату чи й фальсифікації. Як правило, вони не ставлять за мету продукування нового знання, доведення наукової істини, а керуються особистісними, часто матеріальними потребами. Діяльність таких дослідників зовні (тобто формально) відповідає вимогам контролювальних або оціночних органів до оформлення наукових текстів. Але вона є безперспективною і безплідною для подальшого наукового розвитку активності. Ці та інші наслідки процесу масовізації науки створюють глибинні аксіологічні та світоглядні передумови для послідовного нівелювання та сутнісної примітивізації основ та принципів, що є системотворчою основою всього наукового буття. Так, кардинальним трансформаціям піддаються джерельні ідеали науки, відбувається несвідома переоцінка вченим провідного критерію науковості знання (від його об'єктивної істинності до практичної ефективності, комерційної затребуваності і застосування). Усе це є симптомами не стільки інституційної кризи науки, яка, як і раніше, різнопланово розвивається, кількісно і якісно прогресує, постійно нарощуючи масив усіляких знань і технологій, скільки культурної кризи як світоглядного та ціннісного переродження, що й зумовлює хвилю масовізації, забування історичного підгрунтя науки та динамічного набуття нею масової природи (як в онтологічному, так і в аксіологічному аспектах).

Ще один вияв інституційної кризи науки - масовізація наукової діяльності. Розширюється корпус дослідників, які мають звітувати про результати. Те, що раніше робив хороший інженер, зараз співвіднесено з НДДКР (науково-дослідні та дослідно-конструкторські роботи) - сукупність робіт, спрямованих на здобуття нових знань та їх практичне застосування у створенні нового виробу чи технології, і ця робота теж має оцінюватися. Розмивається предметна сфера наукової діяльності, виникають трансдисципліни, інтердисципліни, підмінюється термінологія, профанується мова. Масовий читач оцінює наукові досягнення через тексти, які публікуються у відомих загальнонаукових журналах чи науково-популярних виданнях. Крім того, широке обговорення наукових проблем відбувається у професійних соціальних мережах.

Проблеми етичних норм наукової роботи завжди хвилювали вчених та становили дослідницький інтерес. Народження експериментального природознавства в Новий час сформувало класичний образ ученого, якому притаманні безкорисливість, самокритичність, працьовитість на межі одержимості, ерудованість, гнучкість мислення, багата уява та інтуїція, ентузіазм. Поняття етосу першим сформулював Р. Мертон. «Етос науки це афективно забарвлений комплекс цінностей $\mathrm{i}$ норм, що вважається обов'язковим для людини науки. Норми виражаються у формі розпоряджень, заборон, переваг та дозволів. Вони легітимуються в термінах інституційних цінностей. Ці імперативи, передані настановою і прикладом і підтримувані санкціями, у різних ступенях інтерналізуються вченим, формуючи його наукову совість» [7, с. 769]. 
У період «великої науки» (із 40-х pp. XX ст.) формується типовий учений, коли наука стає масовою професією і піддається масовому об'єктивному соціологічному дослідженню. Поряд із позитивними властивостями вчених були визначені і негативні якості, як-от безпринципність, жадібність (боротьба за гранти, премії, звання), крадіжка (плагіат), консерватизм, заангажованість (відстоювання «своїх» інтересів за рахунок «чужих»). Свого часу Г. Гегель, який цікавився проблемою плагіату або, як він називав його, «вченого злодійства», помітив, що єдина незламна перешкода в поширенні плагіату - почуття честі самого вченого. Інші офіційно введені «кодекси поведінки», «моральні принципи» тощо здатні лише позначити прийняті в суспільстві кордони, які постійно порушуються [1, с. 69]. Може, саме нехтування ціннісним аспектом виховання науковців і робить актуальною проблему плагіату в наукових публікаціях. Згідно зі статистикою $67,4 \%$ відмов у публікації статей у журналах були пов'язані з неправомірною поведінкою, включаючи шахрайство або передбачуване шахрайство $(43,4 \%)$, дубльовану публікацію $(14,2 \%)$ та плагіат $(9,8 \%)$ [12].

Учені використовують різні підходи до визначення та класифікації плагіату.

Дослівний плагіат - копіювання окремих фраз та речень. Перефразування - використання перестановок, синонімів, косметичних змін із метою введення читача в оману стосовно справжнього авторства. Смисловий плагіат - це присвоєння ідей іншого твору. Мозаїчний плагіат - змішання запозичених фрагментів та власного тексту.

Плагіат може бути навмисним та ненавмисним. Виділяється плагіат за участі «авторів-примар», тобто коли один автор пише роботу за іншого. Дуже поширеним є дублювання своїх публікацій. Багато авторів не вважають це плагіатом, оскільки при цьому не відбувається акту крадіжки. Проте некоректно оформлені дублікати власних статей спотворюють публікаційні показники журналів, показники наукової продуктивності окремих учених та наукових колективів.

На думку експертів, дублювання публікацій може бути виправданим у випадках, коли метою $€$ донесення результатів дослідження до принципово іншої читацької аудиторії, коли стаття перекладається іншою мовою тощо. Можна публікувати рукописи дисертацій, постерні доповіді, усні виступи, але з посиланням на попередні праці. Будь-яка вторинна публікація має відповідати декільком умовам. По-перше, редакції обох журналів повинні знати про це та схвалити таку дію. По-друге, стаття повинна ясно і недвозначно висвітлювати основну ідею (наприклад, у заголовку).

На думку американського дослідника науки Дж. Зімана, постакадемічне наукове співтовариство характеризується пошуком не стільки іс- тини, скільки зиску. Зростання комерціалізації науки, перехід на систему грантів, жорстка конкуренція та бажання заробляти призводять до формування нових норм, які відбивають реалії нового етапу розвитку науки [5].

Отже, чи може вчений у ситуації тотальної комерціалізації залишатися «чесним», тобто знайти вихід зі сформульованої в завданні дилеми: «Або бути Чесним професором - чесним, спираючись на місію ЗНО, науково-дослідної установи щодо пошуків істини та передання нових знань, або бути Успішним професором за критеріями гіперпрагматично орієнтованої стратегії розвитку університету як корпорації-організації»? [10, с. 156]. Таким чином, чи ефективно поєднувати виконання вимог наукової та педагогічної етики з вимогами етики ділового (комерційного) успіху?

Інтерес до науки в суспільстві мізерний. У нашій країні лише починають розвиватися форми науково-популярної трансляції знання для широкого кола людей. Крім того, вчені добре знають, наскільки невеликі гонорари за статті, книги та виступи (якщо вони взагалі є), а плата за комерційні лекції не висока і часто не виправдовує зусиль, прикладених на розробку цікавих курсів. Суми грантів не дуже значні, і левову частку їх забирає організація. Так, активний у науковій та освітній сфері учений відповідає уявленням про наукове сумління, але він не може забезпечити собі прибуток, синонімом якого часто $\epsilon$ «успіх». I цей невеликий прибуток вимагає значної метушні: необхідно враховувати інтереси своєї корпорації, збирати незліченні підписи начальників та подавати нескінченні звіти. Справа лише в тому, щоб змістовну порожнечу за допомогою непроникних псевдонаукових виразів видати за високу науку, отримати за це грант, а потім відзвітувати такими ж змістовно порожніми публікаціями. Справедливо стверджувати, що це навіть не «ефективна наука», а пародія на науку.

Зрештою, ще одним прибутковим видом бізнесу став зміст «наукового» журналу, де публікуються автори за плату, або послуги з просування публікацій у видання, що індексуються міжнародними базами даних. Оскільки віднедавна наявність публікацій є умовою не лише здобуття наукового ступеня (звання), а й продовження роботи у виші, попит на такі публікації став колосальним, породивши пропозиції у вигляді барвистих видань, які розпродають сторінки.

На превеликий жаль, якість оцінюється не з точки зору змістовної глибини та унікальності досліджуваної тематики, а просто за кількістю. I не біда, що в цих списках є місце суто комерційним журналам, редакціям яких немає діла до змісту оплачених текстів і до того, скільки вчених читають їхній журнал. Найбільше вітаються й заохочуються публікації в іноземних журналах із міжнародних списків, 
тобто такі статті, які в нашій країні залишаються невідомими. Можна, звичайно, говорити про популяризацію української науки за кордоном, але $€$ ціла когорта дослідників, які серйозно досліджують вітчизняну історію чи історичні аспекти різних галузей вітчизняної науки, що для закордонних дослідників не становить жодного інтересу. Отже, вимога друкуватися зводиться суто до реалізації чиїхось комерційних інтересів. Якщо все можна вирішити за гроші, то знижується якість публікацій, адже вони існують більше для кількості, ніж для виявлення нових наукових фактів.

Виходить, що найкраще оплачуються не ті публікації, які викличуть інтерес і обговорюватимуться, а ті, в яких буде мізерна кількість читачів. Виходить, що наукометричні результати, виходячи із судження про ефективність співробітників, повністю зведені до формальних показників, що ставить хрест на науці в її традиційному розумінні.

Під ефективністю вченого, що живе наукою та освітою, розумілося інше - затребуваність у професійній спільноті. Це означає, що його запрошують публікуватися в багатьох престижних виданнях, кличуть викладати в провідних вишах та виступати на відомих інтелектуальних майданчиках, за нього конкурують великі освітні центри. Ефективний і затребуваний учений - це той, хто може робити щось унікальне, неповторне (наприклад, вести курс на уніальну тематику або публікуватися з питань, із яких існує мінімальна кількість експертів). Але справжня затребуваність, як правило, тягнеться далі за академічне середовище: виступи з коментарями для 3MI, консультування органів влади, участь у соціально значущих проєктах, авторитетність у інших галузях знання та практики.

За допомогою своєї праці він впливає на громадську думку, на інтелектуальну та духовну атмосферу, працюючи для майбутнього своєї країни. Наявність ученого такого рівня в корпорації - безперечний успіх для неї. Але все ж таки для самого вченого успіх і пізнаваність у суспільстві не є головною метою. Його основна робота - зануреність у свою дослідницьку галузь, захопленість справою передання знань майбутньому поколінню вчених, робота зі створення власної наукової школи та оригінального дослідницького напряму. Успішна праця вченого з цих напрямів означає лідерство в науковій галузі i, як наслідок, лідерство в тій галузі корпорації, яку він представляє. Саме тут і буде досягнуто продуктивного поєднання етики індивідуального успіху з етикою корпоративного.

Ефективними викладачами чиновники вважають не тих, хто веде унікальні курси, розвиваючи проривні напрями, а тих, хто бере на себе найбільше навантаження, закриваючи при цьому безліч не зовсім пов'язаних між собою дисциплін. Таке ставлення відповідає загальній тенденції в освіті, за якою об’єднуються кафедри, відділення, фа- культети та цілі університети, причому об’єднання супроводжуються скороченнями викладачів. $\mathrm{y}$ величезних корпораціях співробітники мимоволі змушені ставати фахівцями широкого профілю, ведучи курси і за себе, і за скорочених колег. Це завдає серйозного удару якості вищої освіти: замість поглибленої підготовки за унікальними напрямами студенти отримують гранично узагальнений набір знань, який до того ж транслюють не фахівці, а «ефективні» викладачі широкого профілю. У результаті склалося так, що в реформах, покликаних підвищити «ефективність» університетів, студенти виявилися чи не найголовнішими жертвами цього процесу. Причиною цього є принцип «публікуйся або помри», сформульований американським соціологом Робертом Мертоном, за яким необхідно публікуватися якомога більше всім учасникам освітнього процесу. Критика принципу «публікуйся або помри» широко поширена, а наслідками його застосування в житті наукового співтовариства є такі:

- нарізання наукового дослідження на шматки та публікація безлічі статей замість однієї узагальнювальної та концептуальної;

- збільшення кількості співавторів різного рівня причетності до написання статті, що раніше було характерним для природничих досліджень i значно рідше траплялося в галузі гуманітарних та соціальних наук;

- тенденційність, адже з метою максимізації цитування журнали воліють публікувати статті 3 позитивними результатами дослідження;

- одержимість цитуванням: журнали приділяють підвищену увагу цитованості та маніпулюють імпакт-фактором, а наукові та освітні інституції оцінюють за ним якість наукових досліджень та ухвалюють кадрові рішення;

- цілісність дослідження виявляється під загрозою: маніпуляція експертними оцінками, результати підганяють або відверто підробляють, а про конфлікт інтересів уважають за краще не згадувати [9, с. 165$]$.

Однією із санкцій, що накладаються на вченого, який грубо порушив прийняті правила, є відлучення його від науки - процес, який Томас Ф. Гієрін та Анн Е. Фігерт назвали «церемонія деградації статусу» [2]. Сенс механізму «деградації статусу» очевидний: справжні вчені не допускають підтасовування та обману, а якщо таке трапляється, то це вже не вчені.

Висновки. Масовізація наукової діяльності зміна її мотиваційного ядра та процесуальної специфіки в ментальних категоріях споживчо орієнтованої масової культури - стала результатом не тільки екстрамасофікації особистості сучасних дослідників, змушених орієнтуватися у своїй професійній діяльності на потреби та запити масового суспільства та його культури, а й поступової 
інтромасофикації - прийняття окремими ученими ідеалів та цінностей масової культури. Виявами масовізації наукової діяльності є її динамічна комерціалізація, яка підміняє цілі науки суто особистими інтересами їі представників, та зовнішня імітація справжньої наукової активності.

Вихід із ситуації вбачається у формуванні ціннісного підгрунтя молоді, що активно закладається в дитинстві, примножується в школі, вдосконалюється в ЗВО. Загальнолюдські цінності чесності, інтелектуальності, порядності, відповідальності, творчості мають стати основою для життя й наукових пошуків молодих учених.

\section{Jimepamypa}

1. Баландина Э.Г. Проблема запрета на повтор-плагиат в современной науке. Sociology of science and technology. 2015. Vol. 6. No. 1. P. 65-73.

2. Виноградова Т.В. Этос науки и современная система производства научного знания. Науковедческие исследования. 2018. C. 65-87. URL: https:// cyberleninka.ru/article/n/etos-nauki-i-sovremennayasistema-proizvodstva-nauchnogo-znaniya/viewer.

3. Горохов В.Г. Научно-техническая политика в обществе не-знания. Вопросы философии. 2007. № 11 . С. $65-80$.

4. Казаринова Д.Б. «Массовая наука» на конференции EPSA: опыт включенного наблюдения. Полис. Политические исследования. 2020. № 1. С. 163-169.

5. Лазар М.Г. Этос науки в социологии Р. Мертона: судьба и статус в науковедении. Социология нау ки и технологи. 2010 № 4. URL: http://cyberleninka. $\mathrm{ru} /$ article/n/etos-nauki-v-sotsiologii-r-mertona-sudbai-status-vnaukovedenii.

6. Мамчур Е. А. Образы науки в современной культуре. Москва : Канон, 2008. 400 с.

7. Мертон Р. Социальная теория и социальная структура. Москва : АСТ; Хранитель, 2006. 873 с.

8. Ортега-и-Гассет Х. Восстание масс. Москва : ACT, 2003. $353 \mathrm{c}$.

9. Ушаков Е.В. Философия и методология науки: Москва : Юрайт, 2017. 392 с.

10.Этика профессора. Опыт коллективной рефлексии / под ред. В.И. Бакштановского; сост. М.В. Богданова. Тюмень : ТИУ, 2020. 232 с.

11. NSF Science and engineering indicators 2016. URL: https://www.nsf.gov/nsb/publications/2016/ nsb20161.pdf.

12. Fang, F. C., Steen, R. G., \& Casadevall, A. (2012). Misconduct accounts for the majority of retracted scientific publications. PNAS Proceedings of the National Academy of Sciences of the United States of America, 109(42), 17028-17033. URL: https://doi.org/10.1073/ pnas. 1212247109 .

\section{Анотація}

Герасименко Л. В., Лебединська Г. О. Проблема наслідків масовізації наукової діяльності. - Стаття.

У статті аналізуються проблеми взаємозв'язку моральних норм наукової діяльності та розвитку науко- вого пізнання. У процесі ускладнення та поглиблення наукового пізнання відбувається концептуалізація образу та ідеї етичного потенціалу науки. Актуальність теми пов'язана 3 поширенням плагіату та боротьбою 3 цим явищем у науці. У статті розглядаються проблемні контури масовізації наукового знання. Масовізація науки - аксіологічний процес проникнення в наукове буття ціннісних установок та імперативів масової культури, які, стосуючись особистості вченого, проникають через нього в буття усіх її системоутворювальних граней. Наукова діяльність поступово набула сучасного вигляду та виявів, втративши спочатку властиві їй риси соціокультурної винятковості, неформальності, фрагментарності та езотеричності і набувши сталого статусу масової професії. Виявом масовізації наукової діяльності стала їі широка формалізація - використання під час написання наукових праць прийомів, що конституюють їхню «науковість» лише за суто формальними ознаками та критеріями. Написані в межах «формального» підходу роботи не відрізняються ні пізнавальною новизною, ні дослідницькою глибиною, ні справжнім розкриттям предмета вивчення, ні дійсною актуальністю та є складеними на завуальованій реферативно-плагіативній основі. Наступним виявом масовізації інституту науки є зниження особистісних критеріїв та якостей сучасного вченого, а також тих моральних та етичних вимог, які висуває до нього наукова спільнота та суспільство загалом. Сам спосіб життя масової цивілізації, що характеризується калейдоскопом ідентичностей, розмиває в цьому сенсі елітарний етос науки й образ ученого, який усе більше набуває рис менеджера, а не виробника знань. Автори звертають увагу на етичні підстави відповідальності вченого в реалізації соціальних цілей розвитку наукового пізнання.

Ключові слова: наукова діяльність, масовізація, моральні норми, плагіат.

\section{Summary}

Gerasimenko L. V., Lebedinska G. O. The problem of the consequences of the massification of scientific activity. - Article.

The article analyzes the problems of the relationship between moral norms of scientific activity and the development of scientific knowledge. In the process of complicating and deepening scientific knowledge, the image and idea of the ethical potential of science are conceptualized. The relevance of the topic is related to the spread of plagiarism and the fight against this phenomenon in science. The problem contours of massification of scientific knowledge are considered in the article. Massification of science is an axiological process of penetration into the scientific existence of values and imperatives of mass culture, which, touching the personality of the scientist, penetrate through him into the existence of all its systemforming facets. Scientific activity has gradually acquired a modern form and manifestations, having lost its original features of socio-cultural exclusivity, informality, fragmentation and esotericism, and having acquired a permanent status of a mass profession. Manifestation of the massification of scientific activity was its broad formalization - the use in writing scientific papers of techniques that constitute their "scientificity" only on the basis of external, purely formal features and criteria. The 
works written within the framework of such a "formal" approach do not differ in cognitive novelty, research depth, real disclosure of the subject of study, or real relevance and are sometimes compiled on a veiled abstract-plagiarism basis. The next manifestation of the massification of the institute of science is the reduction of personal criteria and qualities of the modern scientist, as well as the moral and ethical requirements of the scientific community and society as a whole. The very way of life of mass civilization, characterized by a kaleidoscope of identities, erodes in this sense the elitist ethos of science, and with it the image of a scientist who increasingly acquires the features of a manager rather than a producer of knowledge. The authors draw attention to the ethical grounds of responsibility of the scientist in the implementation of social goals of scientific knowledge.

Key words: scientific activity, massification, moral norms, plagiarism. 